\title{
Evaluation of the Impact of Innovation Management on Customer Satisfaction and the Innovative Behavior of Employees: Field Study in Commercial Banks in the State of Kuwait
}

Submitted 18/07/21, 1st revision 15/08/21, 2nd revision 30/09/21, accepted 28/10/21

Fawaz Alhammad $^{1}$, Afaf Bugawa ${ }^{2}$

\begin{abstract}
:
Purpose: This research paper aimed at identifying the impact of innovation management on customer satisfaction and the behavior of innovative employees in commercial banks in Kuwait.

Design/Methodology/Approach: Based on the descriptive-analytical approach, the study used the questionnaire on a sample represented by (5) banks in Kuwait (28\%). After collecting the study data, the Statistical Analysis Program (SPSS) and PLS were used, several results were reached.

Findings: There is a moderate degree of innovation management practice in commercial banks in the State of Kuwait, there are an impact and correlation between innovation management and the innovative climate from one hand and the innovative climate and customer satisfaction, on the other hand. It also showed the impact and correlation between the innovative climate and innovative behavior in the study population. Furthermore, there are an impact and correlation between network theory, innovation management, innovative climate, customer satisfaction, and the behavior of innovative workers.

Practical Implication: The study recommended attention to managing innovation and the innovative climate and strengthening network theory in commercial banks. It also recommended stimulating the work of the Training and Development Department in commercial banks in the State of Kuwait.

Originality/Value: The value of the study comes to find solutions to weaknesses, if any, and to strengths by not losing any sight of management phenomena and variables that contribute to the development of innovation management in commercial banks.
\end{abstract}

Keywords: Innovation management, innovative behavior of workers, innovative climate, network theory, commercial banks in the State of Kuwait.

JEL Codes: M1, M10.

Research Type: Research article.

\footnotetext{
${ }^{1}$ Arabian Gulf University, Department of innovation and technology, Bahrain, Fawaz_wa@hotmail.com;

${ }^{2}$ Arabian Gulf University, Department of innovation and technology, Bahrain
} 


\section{Introduction}

As a result of the rapid technological developments in contemporary economics, the foundations of governance for the success of organizations have changed, putting organizations at stake; This has necessitated the creation of innovative capabilities capable of coping with these rapid changes, making innovation an essential function in modern organizations (Qabajah and Jaradat, 2020) so that organizations of all kinds are seeking to gain as much knowledge as they can lead to innovation and excellence in their sector. The banking sector is one of the most important economic sectors for excellence through its drive for knowledge and innovation (Al Fraihat, 2013).

As a result of organizations being challenged to meet market and customer needs and achieve their goals in today's dynamic and competitive business environment, innovation has gained prominence as a means of dealing with this environment and maintaining performance and growth, as innovation is an essential key for the Organization to ensure its long-term survival and growth (Khaledabadi, 2008).

Innovation management is the process of implementing the new idea into an economically profitable business, and innovation management is seen as a core function of management aimed at creating new sources and resources and exploiting existing resources in a way that maximizes expected production essence, the process of managing innovation is based on how to respond to environmental variables. It is one of the means of bringing about change in the Organization. It is seen as one of the systems or sub-departments within the Organization, which interact, overlap, and integrate with other systems or sub-departments to serve the Organization's changing and renewed objectives and strategies. The innovation management system consists of the following elements: Innovative person, Innovation Technology, innovative Climate, Innovation process, innovative Product/Service (Qandil, 2010).

Over the past few years, innovation has become increasingly crucial in achieving customer satisfaction. Customers demand various products or services, which requires producers - organizations - to create products that meet customers' needs and not just produce new products because innovation leads to sustainable growth and the ability to accommodate customers' demands. The ability to emulate success, so innovation reduces the cost of production, reduces the time to succeed rather than wasting time, effort, and money in developing new products - which do not meet the needs of graduated customers - so innovation is a very convenient tool for customer satisfaction, ensuring the Organization stays on the market and even grow (Daragahi, 2017).

One of the essential features of prominent organizations is their proximity to customers and constant communication, as they are fully aware of their needs, desires, and problems. The proximity of the banks to their customers makes them able to judge the success of their policies and procedures in keeping with what is required for complete customer care (Pemek, 2009). Customer satisfaction is one of the most 
important priorities that banks seek to achieve as one of the most important guarantees for their market survival (Abdullah and Al-Suhaibi, 2020). Customer satisfaction is a strategic competitive advantage because the most satisfied customers are the least likely to change their provider. Many customers also select their investment options based on the customer satisfaction rates of their providers (Saad, 2015).

Customer satisfaction refers to the overall assessment of goods and services by the customer, which is a comprehensive assessment of the Organization's performance after purchasing the product or taking advantage of the service provided, and there have been several attempts to find customer satisfaction indicators/measures based on the econometric models. Perhaps the first of these measures is the measure developed by Sweden in 1989 to measure customer satisfaction in Swedish business organizations; The main dimensions are: Satisfaction marches, which consist of: A well-considered performance, customer expectations, customer satisfaction, customer loyalty complaints, and in 1994, the University of Michigan's School of Management, in collaboration with the National Research Center, was developed to produce the American Customer satisfaction Index; Which are three main groups/dimensions: The satisfaction marches group, the customer satisfaction level group, and the satisfaction group, developed in 1999 by the European Union, the customer satisfaction measurement indicator, which was named after the European Customer satisfaction model, is the latest development phase of the Customer satisfaction Index, on which most studies rely for customer satisfaction measurement, and consists of four key dimensions: Image of the Organization, customer expectations, perceived quality of product/service, and customer interaction elements "Quality of Service" (Awad, 2006), this study is therefore a structured scientific effort to identify the level of application of the Innovation Management and its impact on customer satisfaction in banks in the State of Kuwait.

\section{Literature Review}

Innovation management is a human process in which many variables have to be looked at, as confirmed by previous studies such as (Bezdrob, 2019; Kleysen and Street, 2001; Shanker et al., 2017; Leydesdorff and Ahrweiler, 2013; Kriengsak and Rodney, 2008; Mohammad, 2008) study. By building on the innovative climate variables, network theory, and their impact on the behavior of workers and thus on the customer satisfaction of the study population; The previous studies did not collect these variables in one study to determine their impact, which is what the researcher does in the current study of the possibility of getting out more accurately regarding the study variables and the work of the organizations in the study community.

Previous studies have taken individual elements in the relationship or impact of innovation management on the performance of workers or customer satisfaction and through the relationship or impact of innovative behavior, or the study of innovative climate or network theory on the organization's performance. Thus, they impact customer satisfaction by not going into the details of other variables, knowing their 
combined effect, and excluding that they fall outside the study's limits, which has drawn the researcher's attention to what he will do in the current study.

Therefore, the problem of the study lies in answering the following question: What has the impact of innovation management in achieving customer satisfaction and the behavior of innovative employees in commercial banks in the State of Kuwait?

\section{Research Methodology}

\subsection{Study Questions}

1. Is there an impact of the innovation management on the innovative climate in commercial banks in the State of Kuwait?

2. Is there an impact of the innovative climate on customer satisfaction in the commercial banks of the State of Kuwait?

3. Is there an impact of the innovative climate on the behavior of innovative employees in commercial banks in the State of Kuwait?

4. Is there an impact of Network Theory on the innovation management in commercial banks in the State of Kuwait?

5. Is there an impact of the Network theory on the innovative climate in commercial banks in the State of Kuwait?

6. Is there an impact of the Network theory on customer satisfaction in commercial banks in the State of Kuwait?

7. Is there impact of the network theory on the behavior of innovative employees in commercial banks in the State of Kuwait?

\subsection{Significance of the Study}

The importance of the study comes in order to find solutions to weaknesses, if any, and to strengthen strengths; By not losing sight of management phenomena and variables that contribute to the development of innovation management in commercial banks, and by drawing the attention of organizations to the reality of the impact of innovation management on the satisfaction of their clients, ultimately to the benefit of all: commercial banks, customers and society as a whole; The commercial banking sector has a significant role to play in serving the interests of society. The current study contributes to the apparent lack of knowledge in the Arab Library in the area of the study of innovation and its impact on customer satisfaction and the innovative behavior of banking workers, as illustrated in the study of the innovative climate, thus opening the way for more studies on its topics. This contributes to the enrichment of knowledge.

\subsection{Study Objectives}

1. To identify the impact of innovation management on innovative climate in commercial banks in the State of Kuwait. 
2. To identify the impact of the innovative climate on customer satisfaction in commercial banks in the State of Kuwait.

3. To identify the impact of the innovative climate on the innovative behavior of employees in commercial banks in the State of Kuwait.

4. To identify the impact of network theory on the innovation management in commercial banks in the State of Kuwait.

5. To identify the impact of Network Theory on the innovative climate in commercial banks in the State of Kuwait.

6. To identify the impact of network theory on customer satisfaction in commercial banks in the State of Kuwait.

7. To identify the impact of network theory on the innovative behavior of employees in commercial banks in the State of Kuwait.

The researcher used the survey's descriptive approach, field study method, to gather information from critical resources of literature on the subject of evaluation of innovation management and its impact on customer satisfaction, and to collect data from primary sources through the development of a tool that serves study goals, distributed to members of the study population. The researcher used the descriptive analytical approach using the Social Science Statistical Package Program to analyze the study data collected from the primary sources by developing a questionnaire that serves the study goals and distributed to the study population members; the researcher used the following to build the study tool:

Table 1. References and supporting studies of the study model

\begin{tabular}{|l|rl|}
\hline Variable & studies \\
\hline Independent variable (Innovation & - & Qandil, 2010 \\
management) & - & Mohammed, 2013 \\
& - & Abdel-Razek and Alsanad, 2015 \\
\hline Mediator variable (innovative climate) & - & Shanker et al., 2017 \\
\hline Dependent variable (customer satisfaction) & - & Awad, 2006 \\
& - & Ashok, Day, and Narula, 2017 \\
& - & Naveed, Akhtar and Cheema, 2012 \\
\hline Dependent variable (innovative behavior) & - & Thurlings, Evers, and Vermeulen, \\
& & 2014 \\
\hline Control variable (Network theory) & - & Leydesdorff and Ahrweiler, 2013 \\
\hline
\end{tabular}

Source: Own creation.

A random sample of more than (20\%) commercial banks in the State of Kuwait was selected, (220) questionnaires were distributed to employees in customer service and human resources management departments. (185) questionnaires were recovered after excluding (4) invalid statistical analysis data, (181) questionnaires were analysed (0.84). Several clients have been selected to measure their satisfaction in each bank of the study population in parallel with the number of the study tool distributed to the staff. (181) questionnaires were analysable. This percentage is appropriate for this study and distributed as follows: 
Table 2. Study Sample

Source: Own creation.

\begin{tabular}{|l|}
\hline $\begin{array}{l}\text { Commercial banks from the State of } \\
\text { Kuwait }\end{array}$ \\
\hline National Bank of Kuwait \\
\hline Burgan Bank \\
\hline Kuwaiti Finance Bank \\
\hline Bank of Boubyan \\
\hline Bank of Warbah \\
\hline
\end{tabular}

Study tool validity: To ensure that the questionnaire is accurately presented to a group of arbitrators, the study scale is superficial, well-formulated, and adjusted based on the arbitrators' observations.

Study tool reliability: To ensure the tool's stability, internal consistency is calculated by the equation for Cronbach-Alpha, and the table below shows these parameters, and these percentages are considered appropriate for this study as described below.

\section{Table 3. Study Tool Reliability}

\begin{tabular}{|l|l|}
\hline Domains & Internal consistency \\
\hline Innovation management & 0.93 \\
\hline Innovative climate & 0.91 \\
\hline Innovative workers behavior & 0.91 \\
\hline Network theory & 0.91 \\
\hline Customer satisfaction & 0.93 \\
\hline
\end{tabular}

Source: Own creation.

Table 4 shows five measurements, the factor Loading, where the above ratios show the degree, which each variable received at an indication level $(<0.7)$, where innovative individuals identified innovation management with a ratio (.908), technical innovation with a ratio (.932), and innovation processes with a ratio (.942). Innovative products received (.945), which are accepted in the analysis, and the second vital data showed the innovative climate in which the organization's leadership obtained a percentage (.961). The organization's culture (.957), the work teams received a percentage (.940), and in the innovative workers' behavior domain, the fluency rate was obtained (.916),

The authenticity was obtained (.919), the risk tolerance was obtained (.924). In the network theory domain, the functions obtained a (.923), the relationships obtained (.933), the available resources obtained (.936), and the client satisfaction axis gave the image of the organization (.878). The client's expectations were obtained (.883), Recognized quality (.909), and interaction with the customer (.898), which is statistically acceptable. 
Table 4. Results of the Measurement Model at Commercial banks in the State of

Kuwait

\begin{tabular}{|c|c|c|c|c|}
\hline & & $\begin{array}{l}\text { Ave } \\
\text { Average } \\
\text { Variance } \\
\text { Extracted }\end{array}$ & $\begin{array}{l}\mathrm{CR} \\
\text { Composite } \\
\text { probability } \\
\text { Calculator }\end{array}$ & Loading \\
\hline \multirow[t]{4}{*}{ Manage innovation } & Creative individuals & 0.868 & 0.963 & .908 \\
\hline & Technological innovation & & & .932 \\
\hline & Innovative processes & & & .942 \\
\hline & Innovative products & & & .945 \\
\hline \multirow[t]{3}{*}{ The innovative climate } & Organization leadership & 0.908 & 0.967 & .961 \\
\hline & Organization culture & & & .957 \\
\hline & Work teams & & & .940 \\
\hline \multirow{3}{*}{$\begin{array}{l}\text { Innovative personnel } \\
\text { behavior }\end{array}$} & Fluency & 0.846 & 0.943 & .916 \\
\hline & Authenticity & & & .919 \\
\hline & Risk tolerance & & & .924 \\
\hline \multirow[t]{3}{*}{ Network theory } & Functions & 0.866 & 0.951 & .923 \\
\hline & Relationships & & & .933 \\
\hline & Available resources & & & .936 \\
\hline \multirow[t]{4}{*}{ Customer satisfaction } & Organization image & 0.796 & 0.940 & .878 \\
\hline & Customer expectations & & & .883 \\
\hline & Perceived quality & & & .909 \\
\hline & $\begin{array}{l}\text { Engage with the } \\
\text { customer }\end{array}$ & & & .898 \\
\hline
\end{tabular}

\section{Source: Own creation.}

Table (5) shows the test of hypotheses and study variables, and the load of the hypothesis on the variable, which we measure higher than the load on the remaining study variables. It is clear from the table that all hypotheses have been proven to be the strongest, in this step the validity and integrity of the analysis study hypotheses has been established.

Table 5. Reliability of Cross-loading and differentiation in commercial banks in the State of Kuwait

\begin{tabular}{|l|l|l|l|l|l|}
\hline & $\begin{array}{l}\text { Manage } \\
\text { innovation }\end{array}$ & $\begin{array}{l}\text { Customer } \\
\text { satisfaction }\end{array}$ & $\begin{array}{l}\text { Network } \\
\text { theory }\end{array}$ & $\begin{array}{l}\text { Innovative } \\
\text { personnel } \\
\text { behavior }\end{array}$ & $\begin{array}{l}\text { The } \\
\text { innovative } \\
\text { climate }\end{array}$ \\
\hline innovative individuals & $\mathbf{. 9 3 0}$ & .593 & .850 & .847 & .860 \\
\hline Technological innovation & $\mathbf{. 9 3 4}$ & .610 & .888 & .860 & .886 \\
\hline Innovative processes & $\mathbf{. 9 4 3}$ & .636 & .848 & .856 & .879 \\
\hline Innovative products & $\mathbf{. 9 4 5}$ & .613 & .877 & .895 & .890 \\
\hline Organization leadership & .912 & .608 & .887 & .901 & $\mathbf{. 9 6 3}$ \\
\hline Organization culture & .900 & .618 & .908 & .909 & $\mathbf{. 9 5 6}$ \\
\hline Work Teams & .888 & .569 & .868 & .880 & $\mathbf{. 9 6 4}$ \\
\hline Fluency & .870 & .608 & .866 & $\mathbf{. 9 3 3}$ & .869 \\
\hline Authenticity & .860 & .614 & .888 & $\mathbf{. 9 4 6}$ & .881 \\
\hline
\end{tabular}


Evaluation of the Impact of Innovation Management on Customer Satisfaction and the

Innovative Behavior of Employees: Field Study in Commercial Banks in the State of 10

Kuwait

\begin{tabular}{|l|l|l|l|l|l|}
\hline Risk tolerance & .870 & .610 & .898 & $\mathbf{. 9 4 3}$ & .884 \\
\hline Functions & .882 & .613 & $\mathbf{. 9 4 1}$ & .885 & .871 \\
\hline Relationships & .869 & .584 & $\mathbf{. 9 5 5}$ & .884 & .876 \\
\hline Available resources & .878 & 622 & $\mathbf{. 9 5 3}$ & .908 & .886 \\
\hline Organization image & .597 & $\mathbf{. 9 1 1}$ & .572 & .588 & .551 \\
\hline Customer expectations & .583 & $\mathbf{. 9 0 0}$ & .584 & .590 & .585 \\
\hline Perceived quality & .594 & $\mathbf{. 9 2 0}$ & .572 & .584 & .558 \\
\hline Engage with the customer & .608 & $\mathbf{. 9 0 9}$ & .597 & .604 & .579 \\
\hline
\end{tabular}

Source: Own creation.

Table (6) shows that the average (derivative) variance represented by the values in the diagonal line indicates that the variable's association values with itself are higher than the other study variables; which means that hypotheses do not overlap or duplicate with another variable, the results of the analysis show that each variable with itself is in its highest position compared to other variables, according to the Law of (1981) Fornal and Larcker, showing here that the innovation management variable toward innovation management is (1). It is higher than the variable below it, with the innovative climate is $(0.937)$, with the behavior of the two innovative factors being (0.922), with the network theory being (0.923), and with customer satisfaction (0.654). The innovative climate variable with the innovative climate was (1), with the behavior of innovative agents on (0.934), with network theory (0.924) and customer satisfaction (0.623), and the changing behavior of innovative workers with the behavior of innovative workers received a value (1), with network theory $(0.940)$ and customer satisfaction (0.650). The network theory variable with the network theory also received a value of (1) and, with customer satisfaction, received (0.638), which is the highest value compared to the variables that occur after it, so that the validity and appropriateness of the study variables and the practicality of the analysis, the structural measurement model in commercial banks in Kuwait, as shown in Figure (12), have been verified.

Table 6. Average Variance Extracted (AVE) in commercial banks in the State of Kuwait

\begin{tabular}{|c|l|l|l|l|l|}
\hline & $\begin{array}{l}\text { Customer } \\
\text { satisfaction }\end{array}$ & $\begin{array}{l}\text { Network } \\
\text { theory }\end{array}$ & $\begin{array}{l}\text { Innovative } \\
\text { personnel } \\
\text { behavior }\end{array}$ & $\begin{array}{l}\text { The } \\
\text { innovative } \\
\text { climate }\end{array}$ & $\begin{array}{l}\text { Innovation } \\
\text { Management }\end{array}$ \\
\hline $\begin{array}{c}\text { Innovation } \\
\text { management }\end{array}$ & & & & & 1 \\
\hline $\begin{array}{c}\text { innovative climate } \\
\text { Innovative workers' } \\
\text { behavior }\end{array}$ & & & & 1 & $.937(* *)$ \\
\hline Network theory & & 1 & 1 & $.934(* *)$ & $.922(* *)$ \\
\hline Customer satisfaction & 1 & $.638(* *)$ & $.650(* *)$ & $.623(* *)$ & $.654(* *)$ \\
\hline
\end{tabular}

Source: Own creation. 
Table 7. Correlation coefficients for all the paths linking the Research hypotheses in commercial banks in Kuwait

\begin{tabular}{|l|c|l|l|l|l|l|}
\hline HY PO & Relationship & Decision & $\begin{array}{c}\text { P- } \\
\text { Value }\end{array}$ & $\begin{array}{c}\text { T- } \\
\text { Value }\end{array}$ & $\begin{array}{c}\text { STD. } \\
\text { Error }\end{array}$ & $\begin{array}{c}\text { STD.be } \\
\text { TA }\end{array}$ \\
\hline & $\begin{array}{c}\text { Innovation Management } \\
\rightarrow \text { innovative Climate }\end{array}$ & Supportive & .000 & 38.694 & .025 & .937 \\
\hline $\begin{array}{c}\text { The innovative climate } \rightarrow \text { the } \\
\text { behavior of innovative workers } \\
\text { The innovative climate } \rightarrow \\
\text { customer satisfaction }\end{array}$ & Supportive & .000 & 37.575 & .025 & .934 \\
\hline $\begin{array}{c}\text { Network theory } \rightarrow \text { innovation } \\
\text { management }\end{array}$ & Supportive & .000 & 12.324 & .050 & .650 \\
\hline $\begin{array}{c}\text { network Theory } \rightarrow \text { innovative } \\
\text { Climate }\end{array}$ & Supportive & .000 & 34.517 & .028 & .923 \\
\hline $\begin{array}{c}\text { Network theory } \rightarrow \text { the behavior of } \\
\text { innovative workers }\end{array}$ & Supportive & .000 & 34.846 & .027 & .924 \\
\hline $\begin{array}{c}\text { Network theory } \rightarrow \text { customer } \\
\text { satisfaction }\end{array}$ & Supportive & .000 & 11.956 & .057 & .638 \\
\hline
\end{tabular}

Source: Own creation.

Table 7 shows that all paths coefficients were positive, which is statistically significant at 0.05 . The indication of 0.05 indicates a positive relationship between the hypotheses of the study. It was found after identifying the means and standard deviations of the degree of innovation management practice in commercial banks in the State of Kuwait, descending based on their means (2.53-2.74). Technical innovation ranked first with the highest mean (2.74), while innovative operations ranked last with average arithmetic of 2.53 and the mean of innovation management as a whole was (2.65).

\section{Results and Discussion}

Having verified and tested the hypotheses of the study, we have several key findings: There is a moderate degree of innovation management in commercial banks in the State of Kuwait. As a result, the current study is consistent with (Alfrihat, 2013) study, which found a moderate level of commercial banks' interest in innovation and agreed with (Abdel Razek and Alsanad, 2015) study, which found that the company in question enjoyed commitment and support for innovation from senior management. We recall the (Shekhi, 2016) study, which concluded that Arab banking systems still face many challenges that pose obstacles to their performance and its adoption of innovation, considering the different application societies in previous studies.

It was also found that there is a statistically significant impact and correlation between the innovation management and the innovative climate in commercial banks in Kuwait, which means that there is a correlation and an impact on the presence of innovative individuals, technical innovation, innovation processes, and innovative 
service in the leadership and culture of the Organization and work teams and that the degree of the high practice of innovation management will be reflected in the innovative climate that is a catalyst for innovation in the Organization through its impact on indicators of innovative climate.

There is a statistically significant impact and correlation between the innovative climate and customer satisfaction in commercial banks in the State of Kuwait, which means that there is leadership and a culture of the banks in question and the task forces help to positively reflect the positive image of the banks in question in the client's mind, as well as the client's expectations, interaction and perceived quality. The innovative climate to a high degree of practice will be reflected in the customer satisfaction of the banks in question. (Mohamed, 2013) found a moral impact on the elements of the marketing innovation climate in customer satisfaction with the banking service quality.

The existence of a statistically significant effect and a correlation between the innovative climate and the innovative behavior of commercial banks in the State of Kuwait means that the banks' leadership and culture in question and the task forces help to reflect fluency, authenticity, and risk tolerance positively.

It has been found that both network theory has a high impact on independent (innovation management) and dependent variables (creative worker behavior, customer satisfaction). The impact of network theory has also been high on both the innovation management (independent variable), innovative behavior of workers (dependent variable, customer satisfaction). The impact of network theory has also been relatively moderate for the intermediate variable (innovative climate) in commercial banks in Kuwait, which means that it reflects positively on the study variables.

There is a statistically significant impact and correlation between the innovation management in customer satisfaction and the behavior of innovative workers in commercial banks in the State of Kuwait, which was agreed with (Qabaja and Jaradat, 2020) study, which found that increasing one unit of product innovation led to an increase in competitive advantage, as confirmed in (Abdullah, Al-Sahibi, 2020) study, which found a positive role between the quality of the provision of banking services in its dimensions and the mental image, and the customer's satisfaction, and was implicitly consistent with (Bezdrob and Muamer, 2019) study, which found that innovative organizations in the Department perform better in the long term, also agreed with (Rakeek, 2016) study, which found a moral impact of innovation on all dimensions of the quality of the banking service, and agreed with a study (Naved, Akhtar, and Cheema, 2012), which found a positive relationship between innovation and customer satisfaction, agreed with (Mashri, 2015) study, which found a statistically significant link between innovation and customer satisfaction with the quality of the Bank's banking service, the current study in its part agreed with a study (Foroudi et al., 2016) which found that the ability to innovate affects the reputation of 
the organization, and also agreed with (Yaslioglu, Caliskan, and Sap, 2013) study, which found that innovation in services, processes and management practices played a positive role in raising positive customer values towards the bulk of services provided by companies, and finally agreed with (Kleysen and Street, 2001) study, which found that there was a correlation between the existence of innovative behavior and the innovations in the Organization, and the current study differs with (Ashok, Day and Narula, 2017) study, which found that there is no impact of innovation processes on customer satisfaction, where customer satisfaction is associated with other variables, such as handling, service delivery, and the level of customer dissatisfaction with the transaction.

As a result of the above, in this part of the current study, the new model of study will be clarified, following the results of the test results of the hypotheses, which were consistent with the initial study model adopted at the beginning of the current study, the researcher was required to indicate the new study model after confirming whether it could be included in some intermediate variables or excluded, which is what this study shows, the Smart Partial Least Square (Smart- PLS).

\section{Conclusions}

It was found that the variables of the study were statistically significant and influential in data analysis, and that both the innovative climate and network theory had an impact on innovation management, which in turn affected customer satisfaction and the behavior of innovative workers. Network theory is a control variable that helps to provide ease and liquidity of information in the Organization, which is mainly reflected in study variables. Customer satisfaction is a tool for measuring what organizations do in their various types of work to ensure that there is customer satisfaction in sustaining and fulfilling their desires in the face of intense competition in today's world. The innovative behavior of workers is a variable that reflects on the satisfaction of clients and that directly affects customer satisfaction.

The Department of Innovation reflects on the nature of the achievement of clients' desires, as well as the innovation of ease of action and communication, which is based on the creation of different business mechanisms, the outcome of which is customer satisfaction. The existence of network theory in different organizations with their indicators of jobs, relationships and resources is an important element of what is reflected in the management of innovation, its impact on the innovative climate, customer satisfaction and the behavior of innovative workers. The theory of the network has come as a compressed variable in the study because the Department of Innovation in its work and interaction in different organizations needs information liquidity in different jobs that support an innovative climate to reach customer satisfaction and innovative workers behavior.

Based on these conclusions, the authors make further recommendations: 
1. To promote the work of women in commercial banks in the State of Kuwait by alleviating society by: Awareness-raising campaigns targeting the work of women in banking, as well as facilities for female banking through pregnancy and maternity leave.

2. Despite the great importance of attracting new generations in commercial banks in the State of Kuwait, more attention should be paid to the element of expertise in the permanent hiring of long-experienced skills that is reflected in banking in the study community.

3. To allow employees of commercial banks in the State of Kuwait to encourage learning through flexible durability or soft loans for the payment of educational premiums, with a focus on post-graduate studies.

4. The need to pay attention to the innovation management in commercial banks in the State of Kuwait by promoting the different work of innovation management indicators, such as the presence of innovative individuals, technical innovation, innovative processes and innovative products, in view of the role it plays in the innovative climate and customer satisfaction in working so as to contribute to the performance of the commercial banks in question in general.

\section{References:}

Abdel Razek, R.H., Alsanad, D.S. 2015. Evaluation of Innovation Management in Developing Countries: A Comparative Study. Arab Gulf Journal of Scientific Research, 33(1), 1-10.

Abdullah, B.M., Sahib, A.N.I. 2020. The quality of banking services has affected customer satisfaction by building a positive mental image in a field study at banks operating in Sana'a Yemen. Journal of Economic, Administrative and law Sciences, 4(6), 32-61.

Al - Saad, M. 2015. Impact of re-engineering the administrative process on customer satisfaction: Irbid Province Electricity Company as a study case, MA thesis, Yarmouk University, Faculty of Economics and Administrative Sciences, Jordan.

Alfreihat, K. 2013. The level of innovation in the banking services and its relationship with competitive advantage for commercial banks in Jordan from managers' perspective, non-published masters' thesis. Yarmouk University, faculty of Business and Economic, Jordan.

Ashok, M., Day, M., Narula, R. 2018. Buyer (dis) satisfaction and process innovation: The case of information technology services provision. Industrial Marketing Management, 68, 132-144.

Awad, M.S. 2016. Determinants of the quality of accounting services and their impact on customer satisfaction in Jordan from a marketing point of view. Arab Journal of Management Sciences, 13(2), 175-195.

Baer, M., Frese, M. 2003. Innovation is not enough: Climates for initiative and psychological safety, process innovations, and firm performance. Journal of Organizational Behavior: The International Journal of Industrial, Occupational and Organizational Psychology and Behavior, 24(1), 45-68.

Bezdrob, M. 2019. Long-Term Performance Implications of Management Innovation. JEEMS Journal of East European Management Studies, 24(2), 210234. 
Bezdrob, M. 2019. Long-Term Performance Implications of Management Innovation. JEEMS Journal of East European Management Studies, 24(2), 210234.

Daragahi, G.A. 2017. The impact of innovation on customer satisfaction: A study of the cosmetics producer in Tehran. International Review, (1-2), 121-132.

Experts of the Management Professional Expertise Centre (PMEC). 2006. Customer Care Skills, L.L.C

Foroudi, P., Jin, Z., Gupta, S., Melewar, T.C., Foroudi, M.M. 2016. Influence of innovation capability and customer experience on reputation and loyalty. Journal of business research, 69(11), 4882-4889.

Khaledabadi, H.J., Magnusson, T. 2008. Corporate social responsibility and knowledge management implications in sustainable vehicle innovation and development. Communications of the IBIMA, 6, 8-14.

Kleysen, R.F., Street, C.T. 2001. Toward a multi-dimensional measure of individual innovative behavior. Journal of intellectual Capital, 284-296

Leydesdorff, L., Ahrweiler, P. 2014. In search of a network theory of innovations: Relations, positions, and perspectives. Journal of the Association for Information Science and Technology, 65(11), 2359-2374.

Mashri, S. 2015. The impact of marketing innovation on customer satisfaction with the quality of banking service in Algerian banks: Field study of the Farm and Rural Development Bank BADR - Wadi Agency, MA thesis, University of the Martyr Hameh Lahadr balwady, Faculty of Economic, Commercial and administrative Sciences, Algeria.

Naveed, T., Akhtar, I., Cheema, K.R. 2012. The impact of innovation on customer satisfaction and brand loyalty: A study of the students of Faisalabad.

Panuwatwanich, K., Stewart, R.A., Mohamed, S. 2008. The role of climate for innovation in enhancing business performance. Engineering, Construction and Architectural Management, 407-422.

Qabaja, A., Jaradat, N. 2020). The impact of innovation on achieving competitive advantage in the industrial companies in Hebron. Economic, Administration and Law Sciences Journal, 4(5), 21-40.

Qandeel, A. 2010. Management Leadership and Innovation Management, Aaman-Jordan, Dar Al-Fikr, Publishers and Distributors.

Rakeek, Z. 2016. Impact of marketing innovation on the quality of banking services: Case Study of the Gulf Bank of Algeria AGB Al Masila Agency, Mohamed Khedir University, Faculty of Economic, Commercial and Management Sciences, Algeria. 1- 117.

Shanker, R., Bhanugopan, R., Van der Heijden, B.I., Farrell, M. 2017. Organizational climate for innovation and organizational performance: The mediating effect of innovative work behavior. Journal of vocational behavior, 100, 67-77.

Thurlings, M., Evers, A.T., Vermeulen, M. 2015. Towards a model of explaining teachers' innovative behavior: A literature review. Review of Educational Research, 85(3), 430-471.

Yaşlıoğlu, M., Çalışkan, B.Ö, Şap, Ö. 2013. The role of innovation and perceived service quality in creating customer value: A study on employees of a call center establishment. Procedia-Social and Behavioral Sciences, 99, 629-635. 